\title{
Cassava flour separation using inverse cyclone
}

\author{
Carlos A. Herrera ${ }^{1}$, Miguel E. Rosillo ${ }^{1}$ \& Alberto García ${ }^{2}$
}

\begin{abstract}
In developing countries cassava starch is produced mostly rurally using artisan methods through wet-way processes that consume as much as $37 \mathrm{~m}^{3}$ of water per processed ton. In comparison, the little industrial production consumes $5 \mathrm{~m}^{3}$ of water per processed ton. These waste waters, highly contaminated, are usually discharged in to the rivers without any treatment. With the aim of industrializing the cassava flour production, CIAT and CLAYUCA are developing an alternative dry technology, environmentally sustainable, to produce enriched flour as a starch substitute. The intention is to separate the starch enriched flour $(<44 \mu \mathrm{m})$ from the fiber rich coarse flour $(>44 \mu \mathrm{m})$. The use of an inversely operated cyclone (related to the conventional operation) showed good potential in terms of efficiency and economy. In this paper we propose pressure drop $(\Delta \mathrm{p})$, fines $(<44 \mu \mathrm{m})$ recovery efficiency $(\eta)$, and fines recovery quality $(q)$, as main functional parameters to characterize the apparatus. Results show that $\Delta p, \eta$, and $q$ only depend on gas velocity $\left(\mathrm{v}_{\mathrm{g}}\right)$ and on the feed solid concentration (c). The $\eta$ and q magnitudes, approximately 60 and $80 \%$ respectively, demonstrate the effectiveness of this technique. Potential improvements merit further exploration.
\end{abstract}

Keywords: yucca, yucca starch, flour separation, rural starch production

\section{Separação de farinha de mandioca em um ciclone inverso}

\section{RESUMO}

Nos países em desenvolvimento, a maioria do amido de mandioca é produzido ruralmente, via úmida e com consumo de $37 \mathrm{~m}^{3}$ de água por tonelada processada. A minoritária produção industrial consome $5 \mathrm{~m}^{3}$ de água por tonelada processada. Estas águas altamente poluentes são descarregadas nàs correntes superficiais, sem tratamento adequado. Para industrializar a mandioca e fazer os processos ambientalmente sustentáveis, CIAT y CLAYUCA estão desenvolvendo tecnologias alternativas de produção seca de farinha enriquecida, elemento substitutivo do amido. A finalidade é separar a farinha fina enriquecida em amido $(<44 \mu \mathrm{m})$ da farinha grossa rica em fibra $(>44 \mu \mathrm{m})$. O uso de um ciclone operado de maneira inversa à convencional, mostrou-se como alternativa muito promissóro em termos de efetividade e economia. Aqui propõese, como parâmetros de desempenho do dispositivo, a queda de pressão $(\Delta p)$, a efetividade $(\eta)$ de captura de finos menores de $44 \mu \mathrm{m}$ e a qualidade (q) dos finos capturados. As provas mostram que $\Delta p, \eta$, e q depende da velocidade de entrada ao ciclone $\left(\mathrm{v}_{\mathrm{g}}\right)$ e da concentração (c) de sólidos na alimentação. As $\eta$, e q obtidas (60 e 80\%) mostram a capacidade da técnica e necessidade de se explorar.

Palavras chave: farinha de tapioca, amido de tapioca, produção rural de amido

School of Mechanical Engineering, Universidad del Valle, AA 25360 - Cali - Colombia. E-mail: cherrera@univalle.edu.co; mrosillo@univalle.edu.co. Fone: 572-321 2137.

${ }^{2}$ Consorcio Latinoamericano de Apoyo a la Investigación y Desarrollo de la Yuca CLAYUCA, Palmira, Colombia. E-mail: jalbertog983@hotmail.com. Fone: $572-445$ 0159 


\section{INTRODUCTION}

Cassava or Yucca (Manihot esculenta) is a tubercle 5 to $10 \mathrm{~cm}$ in diameter and 15 to $35 \mathrm{~cm}$ in length. It is produced in almost all mild and tropical countries and grows in poor soils where almost nothing else progresses. It needs no fertilizers, insecticides, or water. Furthermore, cassava can be harvested any time between 8 to 24 months after planting (FAO Noticias, 2000; Valdivieso García, 2000). Native to America (Domínguez et al., 1980) cassava has historically been a human and animal feed source, and currently has many industrial applications. More than 500 million people have cassava as part of their daily diet. The world wide production reached 160 million tons in 1999, and FAO anticipates an increase to 210 million tons for the year 2005 (FAO Noticias, 2000).

Cassava flour is a potential substitute for corn, rice, and wheat flours, which are usually imported in developing countries. Nutritional facts for cassava and other food products are compared in FAO Noticias (2000).

The main industrial cassava uses are starch extraction, carburant alcohol production, and animal food (Best \& Gómez, 1980; Satin, 1999). The cassava mechanization process is incipient and can be seen in a few rural micro-plants. In Colombia and in other regional countries, cassava production competes with coca and ampoule, which are prime material for illegal drugs fabrication. This fact suggests that large scale cassava growing massive yield and industrialization could be part of the national and international strategies for illicit crops substitution (Presidencia de la República de Colombia, 2003).

In Colombia, cassava starch production is wet-way done achieving both sour and sweet starches. The main process includes the following operations: washing and skinning off the tubercle, then mashing it up to pulp point, afterwards mixing with water, continuing to a screening or filtering process to eliminate fiber, followed by starch separation, and finally, drying the produce to the desired moisture content. It is estimated (Barona \& Isaza , 2003) that $9.5 \mathrm{~m}^{3}$ of waste water are generated per ton of processed fresh cassava, it represents high charges of DQO (Chemical Oxygen Demand between 3000$7000 \mathrm{mg} \mathrm{L}^{-1}$ (Duque, 1994)), DBO (Biochemical Oxygen Demand), dissolved solids, and cyanide compounds that react releasing cyanhydric acid (HCN). On one side, sour starch is produced by artisan techniques in small rurally located units known as "rallanderías", employing around $37 \mathrm{~m}^{3} \mathrm{t}^{-1}$ of wa- ter (Barona \& Isaza, 2003); on the other side, sweet starch is technically extracted and consumes much less water, between 5 to $10 \mathrm{~m}^{3} \mathrm{t}^{-1}$ (Dufour \& Alarcón, 1998). Both processes indeed, either way pollute. To alleviate the generated contamination, which mostly affects rivers, it would be necessary either to implement residual water treatment plants which would make the process expensive, or to use dry-way technologies where the water consumption would be reduced to $0.6 \mathrm{~m}^{3} \mathrm{t}^{-1}$ of processed cassava (just for washing) (Barona \& Isaza, 2003)

Among early developments there is an initiative lead by international organizations CIAT (International Center for Tropical Agriculture) and CLAYUCA (Latin American and Caribbean Consortium to Support Cassava Research and Development), which are looking for practical solutions for cassava industrialization and its massive extension. The CLAYUCA consortium is developing a mechanically simple dry-way technique for starch enriched flour production, which may substitute sweet starch in some industrial processes. During several exploratory test conducted by CLAYUCA in its pilot plant located in Cali, it was accidentally discovered that an inversely fed cyclone produces a good coarse-fine flour separation, an advantage that deserved to be explored. An inverse cyclone (different to the conventional one) is a cyclone in which the inlet solid-gas stream flows axially through the top entrance, and leaves through the tangent outlet.

A technical literature review found no previous research on inverse cyclone operations, and thus its physics is not yet known. There is, therefore a need to perform preliminary test in order to characterize and visualize this separation phenomenon.

The objective of this research is to determine the functionality of the inverse cyclone as a component of the CLAYUCA dry technique. To reach this, the apparatus is characterized by three main parameters: pressure drop, fines recovery efficiency and fines recovery quality.

\section{MATERIALS AND METHODS}

According to Satin (1999) and Barona \& Isaza (2003), the most important physical property of starch granules is their size, ranging between 4 and $40 \mathrm{~mm}$. This information, and the enriched flour properties obtained in preliminary CLAYUCA's trials are shown and compared in Table 1,

Table 1. Functional physical properties of various flours

\begin{tabular}{|c|c|c|c|c|c|c|c|c|}
\hline \multicolumn{2}{|c|}{ Sample } & $\begin{array}{c}\text { Fiber } \\
(\%)\end{array}$ & $\begin{array}{c}\text { Protein } \\
(\%)\end{array}$ & $\begin{array}{l}\text { Ash } \\
(\%)\end{array}$ & $\begin{array}{l}\text { Starch } \\
(\%)\end{array}$ & $\begin{array}{c}\text { Amylose } \\
(\%)\end{array}$ & $\begin{array}{c}\text { Amylopectin } \\
(\%)\end{array}$ & $\begin{array}{c}\text { Moisture } \\
(\%)\end{array}$ \\
\hline \multicolumn{2}{|l|}{ Sweet Starch } & 0.15 & 0.19 & 0.37 & 94 & 17.5 & 82.50 & 4.99 \\
\hline \multirow{2}{*}{ Whole Cassava Flour } & Skinned & 3.04 & 1.75 & 2.36 & 79 & 8.30 & 91.70 & 6.39 \\
\hline & Skin-off & 2.07 & 2.53 & 2.18 & 77 & 11.5 & 88.52 & 8.28 \\
\hline \multirow{2}{*}{ Fine 4 Cassava Flour } & Skinned & 1.87 & 1.62 & 2.10 & 83 & 9.68 & 90.32 & 7.00 \\
\hline & Skin-off & 1.24 & 2.00 & 2.01 & 82 & 10.2 & 89.82 & 7.04 \\
\hline \multirow{2}{*}{ Fine Cassava Flour } & Skinned & 1.62 & 1.43 & 1.98 & 87 & 9.90 & 90.10 & 7.98 \\
\hline & Skin-off & 1.03 & 1.81 & 2.17 & 84 & 11.2 & 88.77 & 8.28 \\
\hline \multirow{2}{*}{ Coarse Cassava Flour } & Skinned & 5.7 & 3.76 & 3.31 & 50 & 1.25 & 98.75 & - \\
\hline & Skin-off & 4.62 & 2.67 & 2.62 & 81 & 3.11 & 96.89 & - \\
\hline
\end{tabular}


where the physical and chemical properties suggest different ways to separate fines (less than $44 \mu \mathrm{m}$ ) from coarse (higher than $44 \mu \mathrm{m}$ ). Particular attention is drawn to getting higher starch amount within the fines fraction at lower fiber and ash contents than the whole flour. Sweet starch is usually wet-way produced which means that the water is a major vehicle of transportation in the process, and as already explained, generates high contaminant charges.

Figure 1 shows the proposed process, which uses raw cassava pieces (12\% moisture) as a prime material, and where starch enriched flour is the main product. This technique consists of a milling process parallel to a solid-solid and solid-gas separation. The raw matter (cassava chunks)

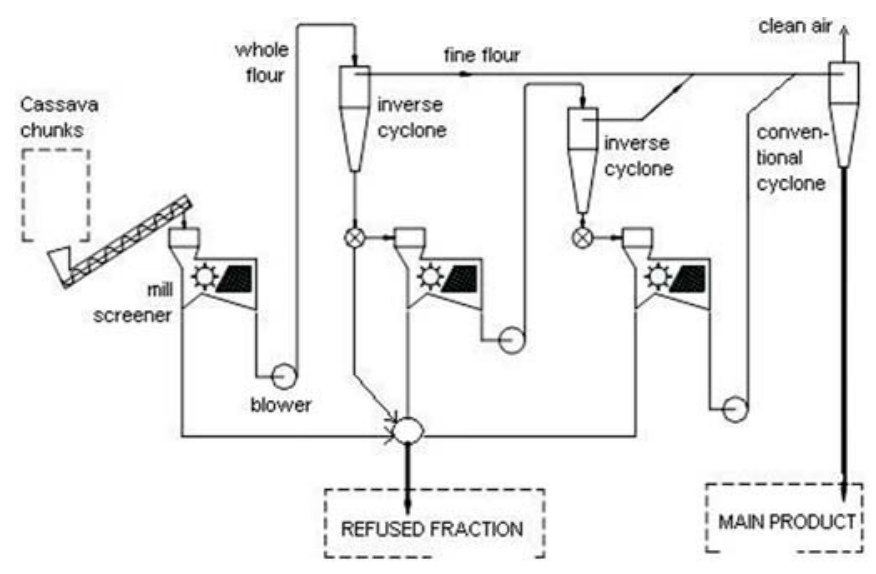

Figure 1. Plant flow layout is fed toward a mill-screener device obtaining whole flour and refused fraction. The refused fraction constitutes a byproduct that is packed for other uses; in the meantime, the whole flour continues to the inverse cyclone separation (the new solid-solid separation which is investigated and described in this paper). In this apparatus the flour is disaggregated into fine flour ( $<44 \mu \mathrm{m}, 87 \%$ starch) and coarse flour $(>44 \mu \mathrm{m})$. The course flow can be packed either as a by-product or returned to a second or third milling and separation phases. The fine flour is recovered through a conventional cyclone and constitutes the main product, as already mentioned.

In addition to the inverse cyclone, the solid-solid separation can be done by other means like: screens, conventional cyclones, commercial available third generation separators (CIM-MICROSEP, 2005), or any other applicable method. CLAYUCA experimented with screen separation and found particle agglomeration that causes the operation to collapse (Barona \& Isaza, 2003); third generation separators are unaffordable for small and medium rural producers (Barona \& Isaza, 2003), and conventional cyclones for this application result in extremely large devices (7 m diameter, $30 \mathrm{~m}$ height) which are impractical and high-priced.

For the study purposes, CIAT-CLAYUCA built an experimental laboratory which included mill-screenerblower-inverse cyclone and conventional cyclone, as shown in Figure 2A, and a clear acrylic cyclone shown in Figure 2B.

The mill-screener handles up to $145 \mathrm{~kg} \mathrm{~h}^{-1}$ of dry cassava
A.

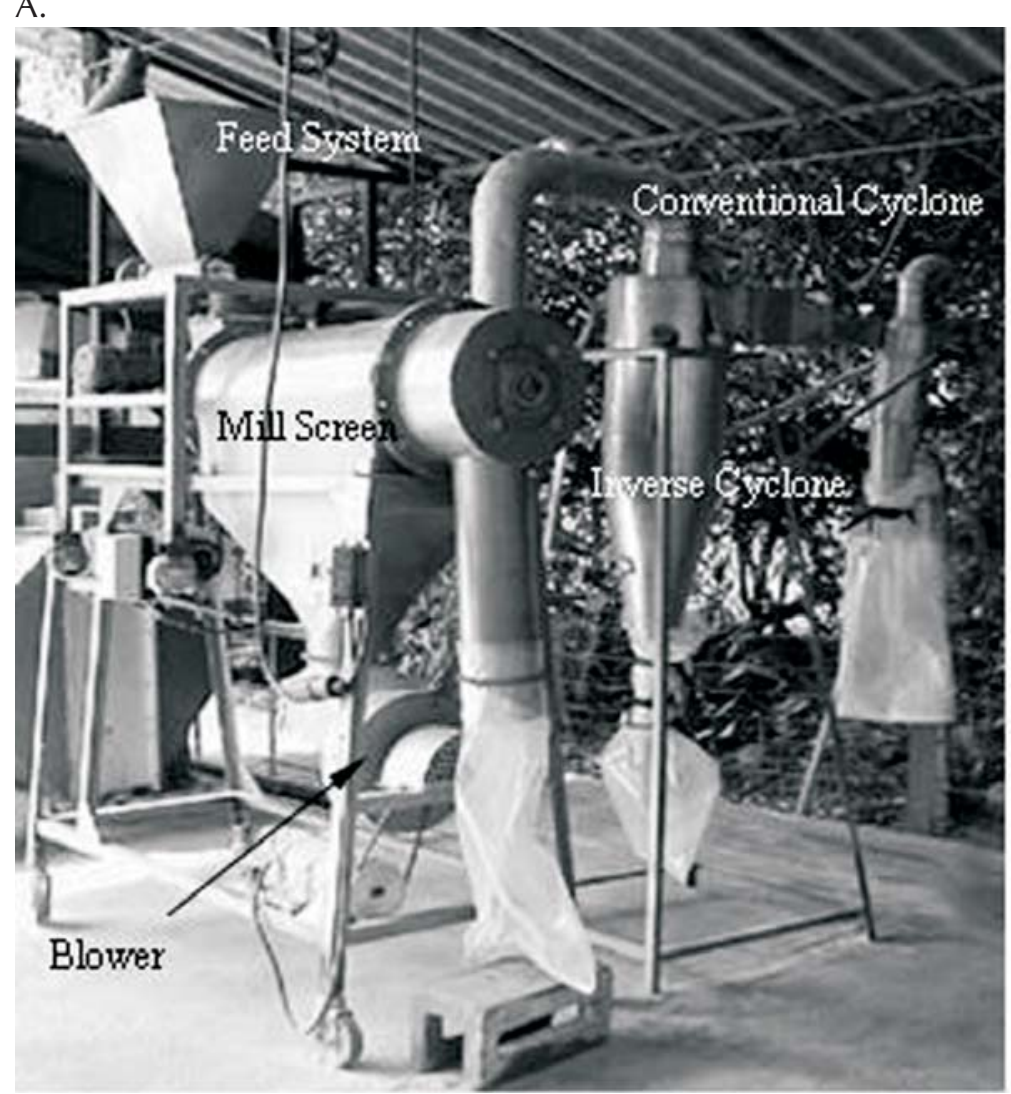

B.

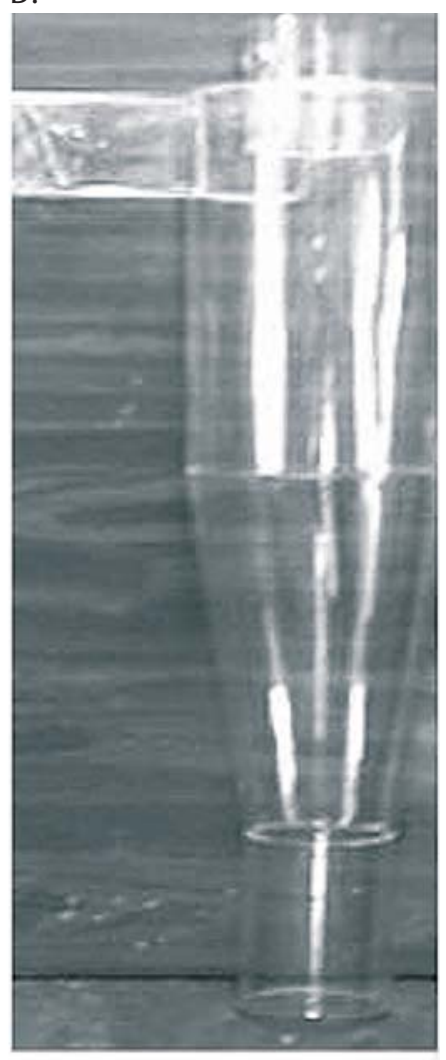

Figure 2. Experimental equipment at CLAYUCA installations in Cali (A). Transparent acrylic cyclone (B) 

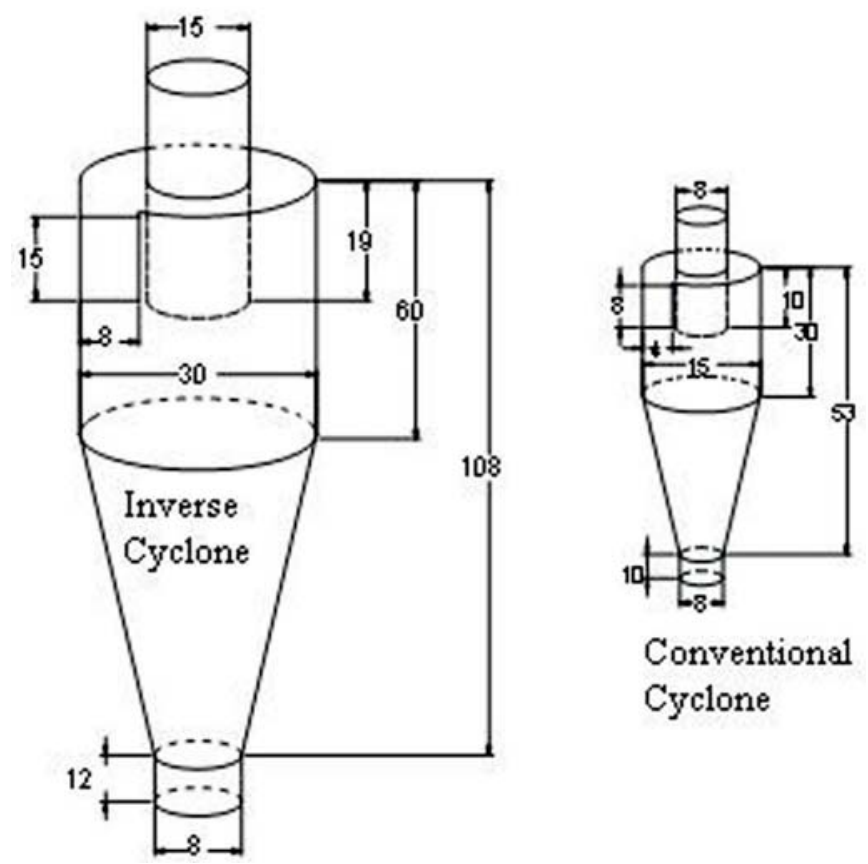

Conventional Cyclone

Figure 3. Cyclone dimensions (cm)

chunks. The transparent acrylic cyclone has the same size as the inverse cyclone and their dimensions are shown in Figure 3. The blower is a centrifugal fan with 12" diameter, straight radial blades $1735 \mathrm{rpm}$ and a $1.5 \mathrm{~kW}$ (2 HP) motor.

\section{RESULTS AND DISCUSSION}

The inverse cyclone, as illustrated in Figure 4, has one inlet named FEED, and two outlets: the axial lower outlet called HEAVIES, and the tangential upper outlet called LIGHTS. Its main purpose is to recover (amid the LIGHTS) the most part of enriched flour ("fines" $<44 \mu \mathrm{m}$ ) and the less part of coarse flour ("coarse" $>44 \mu \mathrm{m}$ ). According to this, the most representative parameters of the inverse cyclone behavior are: powder-air concentration $\gamma\left(\mathrm{g}_{\text {powder }} \mathrm{m}^{-3}\right.$ air $)$ among FEED, pressure drop $\Delta \mathrm{P}(\mathrm{Pa})$, inlet velocity $\mathrm{v}_{\mathrm{g}}\left(\mathrm{m} \mathrm{s}^{-1}\right)$, recovery efficiency $\eta\left(\mathrm{m}_{\text {fines-LIGHTS }} / \mathrm{m}_{\text {fines-FEED }}\right)$, and LIGHTS quality q $\left(\mathrm{m}_{\text {fines-LIGHTS }} / \mathrm{m}_{\text {LIGHTS }}\right)$. Thus, the efficiency $\eta$ can be described as the fraction of captured fines among the LIGHTS respect to fines among the FEED (\%), and the quality (q) as the fraction of fines among the LIGHTS (\%).

The methodology consisted of using three different FEED mass flow rates $\left(24,45\right.$ and $\left.100\left(\mathrm{~kg}_{\text {flour }} \mathrm{h}^{-1}\right)\right)$; each one tried at several different velocities (10.9, 15.2, 18.8 and $21 \mathrm{~m} \mathrm{~s}^{-1}$ ). HEAVIES and LIGHTS grain size, mass flow rates, and velocities were measured for all tests. The FEED grain size was fixed for all trials at $72 \%$ fines and $28 \%$ coarse. A Ro-Tap classifier was used for grain sizing.

In agreement to the described tests, and focusing on visualizing and comparing conventional and inverse cyclones flow patterns, an ample range of tests in the transparent acrylic cyclone were performed and video recorded. The

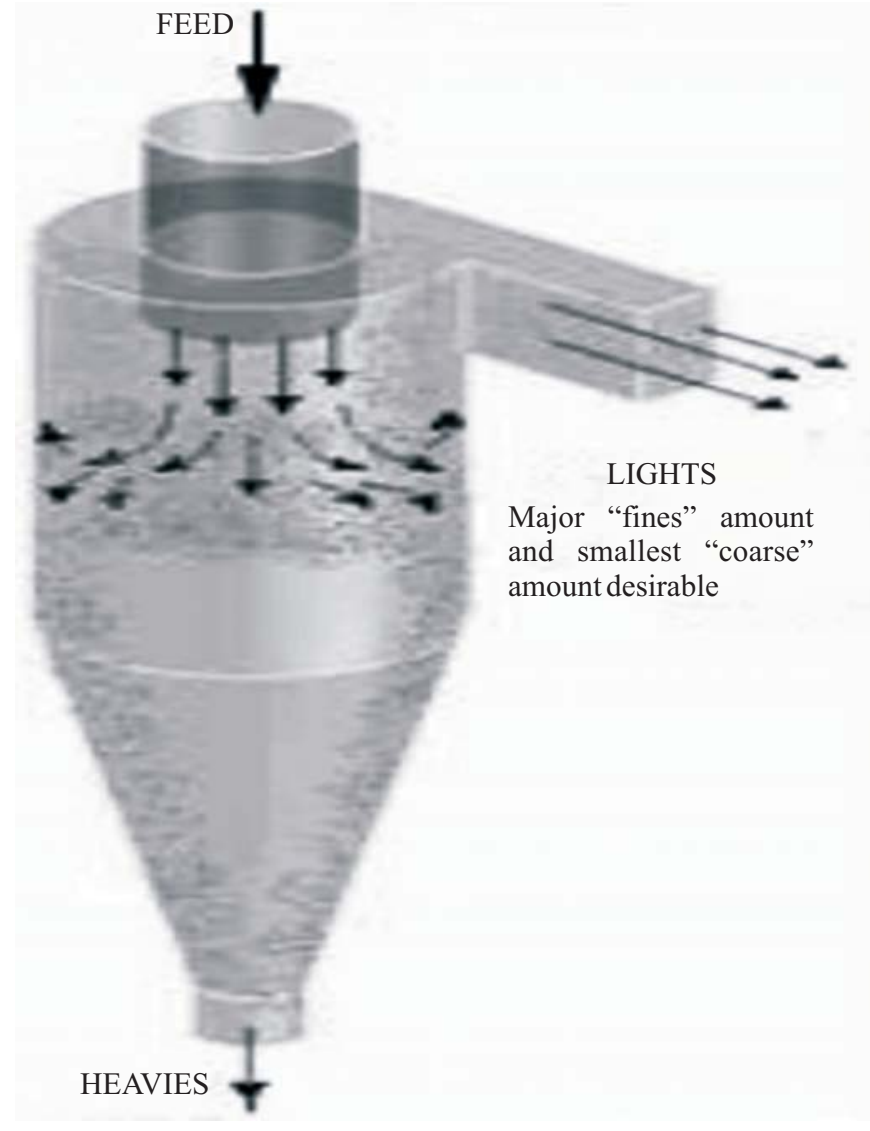

Figure 4. Inverse Cyclone Performance

helicoidally flow pattern featured the conventional cyclone as well as the inverse cyclone flow pattern shown in Figure 5 can be clearly seen. It was also observed HEAVIES agglomeration at the cone lower part of the inverse cyclone; meanwhile, at the medium part of the cylinder, it could be seen the air and fines returning through the peripheral zone.
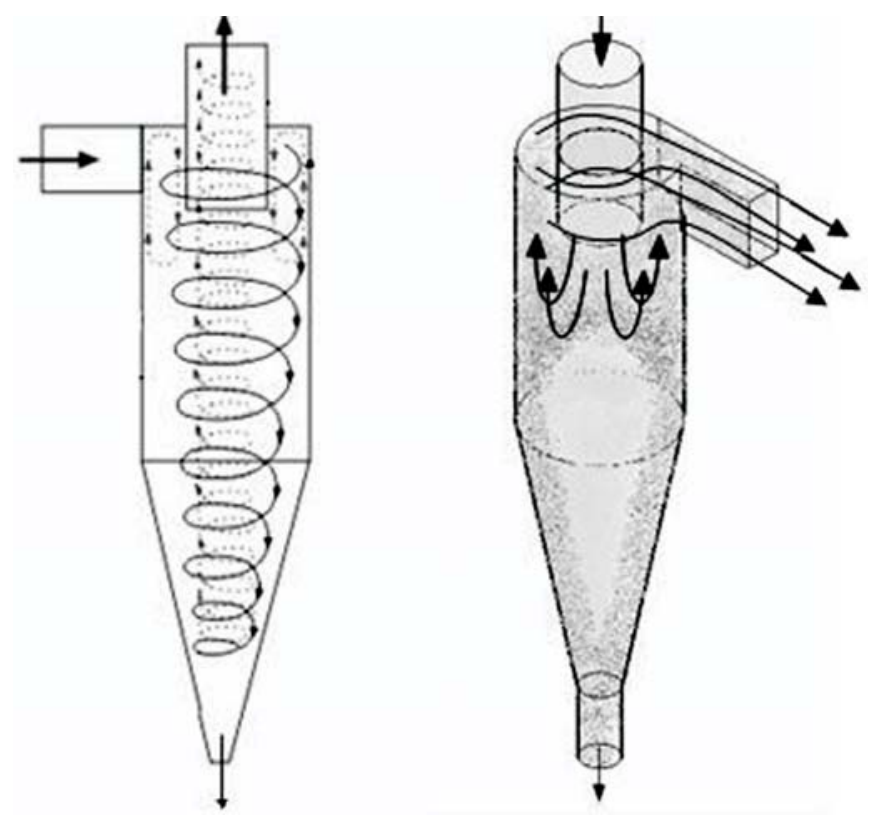

Figure 5. Conventional and Inverse Cyclone Flow Patterns 
The conventional cyclones pressure drop is comprehensively treated in the technical literature (Shepherd \& Lapple, 1940; Casal \& Martínez-Benet, 1983; Stairman, 1949). The pressure drop is usually expressed in terms of the inlet velocity head according to:

$$
\Delta \mathrm{P}=\frac{1}{2} \rho_{\mathrm{g}} \cdot \mathrm{v}_{\mathrm{g}}^{2} \cdot \mathrm{NH}
$$

where $\Delta \mathrm{P}$ is the pressure drop, $\mathrm{v}_{\mathrm{g}}$ is the gas velocity at cyclone inlet, $\rho_{\mathrm{g}}$ is the gas density and the factor $\mathrm{NH}$ according Casal \& Martínez-Benet (1983) is

$$
\mathrm{NH}=11.3\left(\frac{\mathrm{a} \cdot \mathrm{b}}{\mathrm{D}^{2}}\right)^{2}+3.33
$$

where $\mathrm{a}, \mathrm{b}$ and $\mathrm{D}$ are the entrance height, entrance width, and the cyclone diameter respectively.

Figure 6 illustrates that the pressure drop predicted by Eqs. (1) and (2) for conventional cyclones more than doubles the one for inverse cyclone. This result becomes an important advantage since the blower power requirements reduce for inverse cyclone arrangements. The inverse cyclone pressure drop can be anticipated (conservatively) using Eq. (3):

$$
\Delta \mathrm{P}_{\mathrm{inv}}=0.7972 \mathrm{v}_{\mathrm{g}}^{2}
$$

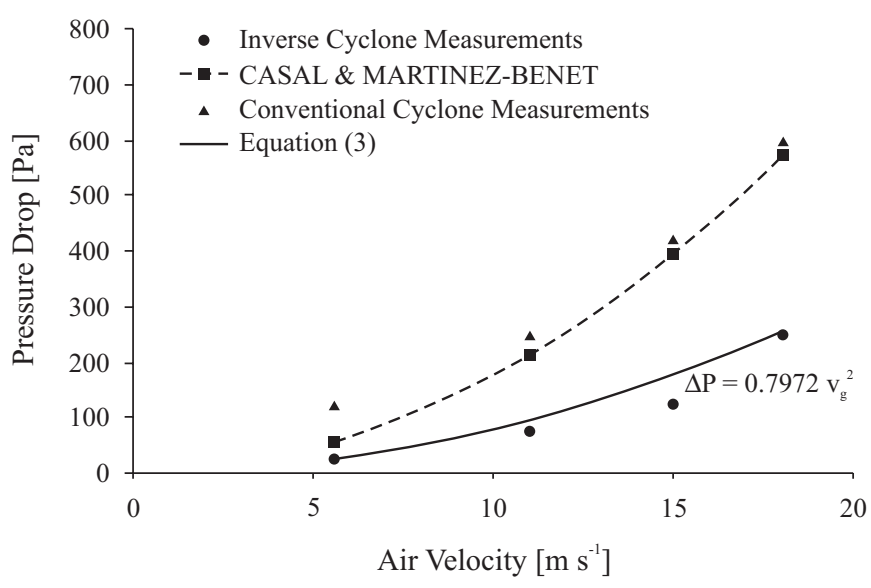

Figure 6. Pressure drop comparison

The most important parameter for the inverse cyclone is the efficiency $(\eta)\left(m_{\text {fines-LIGHTS }} / m_{\text {fines-FEED }}\right)$, that represents the capacity to separate enriched flour ("fines"), which depends (for a fixed cyclone) on the FEED fine concentration and the inlet gas velocity.

The most desirable results are to get high efficiencies at high concentrations, and low operation velocities, because they represent low power consumption, low pressure drop, and more plant capacity. According to the observed data in Figure 7, it is first noted that for a fixed velocity the best efficiencies appear at low powder concentration, which is an undesirable effect. It is also observed that the point of acceptable efficiencies ( 60\%) for all velocities and the best position for high concentration (point A) occurs, fortunately, at the lowest velocity.

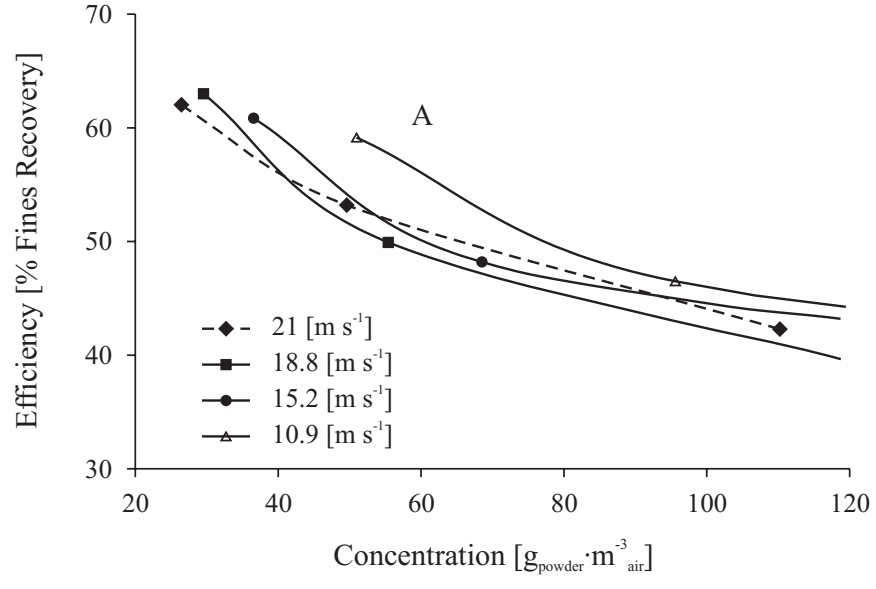

Figure 7. Recovery efficiency vs. concentration \& velocity

Another vital parameter is the LIGHT's quality (q), that means how clean (no coarse presence) is the product. The unwanted coarse drag or dirtiness (and therefore the quality) depends on FEED powder concentration (c), inlet velocity $\left(\mathrm{v}_{\mathrm{g}}\right)$, and cyclone geometry. Figure 8 shows the concentration and velocity effect on the LIGHT's quality for the described cyclone.

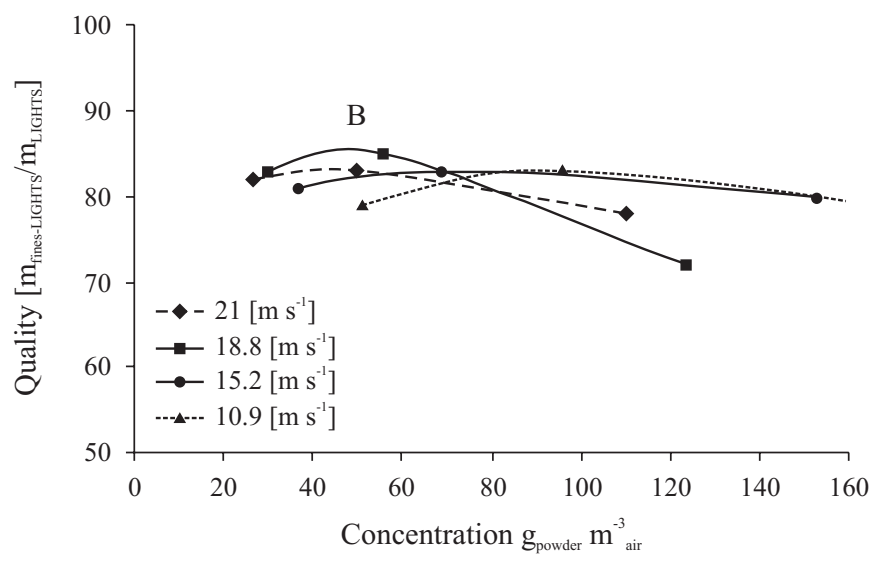

Figure 8. LIGHTS quality vs. concentration \& velocity

Analogous to efficiency, high qualities, high concentrations, and low velocities are desirable for best performance. In Figure 8 it can be seen that for a fixed velocity there exist one powder concentration which gives maximum quality. It is also noticeable that all quality maxima results at the same order of magnitude ( $~ 82 \%)$, thus, point B is the best result for operating the apparatus in terms of quality, though neither the powder concentration nor the gas velocity are the best ones.

Results show that points A and B are at the same velocity but different concentrations; however, meanwhile point B efficiency is poor (47\%), point A quality (79\%) is of the same order of magnitude as the maximum quality. This means that point $\mathrm{A}$ is a suitable point to operate the inverse cyclone reaching the highest efficiency at almost maximum quality. 


\section{CONCLUSIONS}

1. An alternative method for dry-way starch enriched flour production developed by CIAT and CLAYUCA is presented. Contrary to the conventional wet-way method, this option in much cleaner, mechanically simple, and consists in separating fines from coarse flour since starch is concentrated in the fines. The enriched flour is a potential substitute for starch in many industrial processes.

2. It was found that the main process parameters are gas flow cyclone inlet velocity, FEED powder concentration, and cyclone size. Furthermore, promising economic and technical feasibility perspectives were visualized through LIGHTS quality and recovery efficiency results.

3. Further experiments are necessary to consolidate the new technique. The efficiency curves showed clear tendencies and positive results at tested velocities; thus additional tests at other velocity ranges are worthwhile. In addition, different cyclones geometries should be explored.

4. Inverse cyclone pressure drop is lower than the one for conventional cyclones, which is favorable for blower power requirements. An equation to compute its pressure drop is available.

5. The discussed dry-way cassava starch production method offers an economic, practical and feasible technique; even more, it is a good environmental sustainable alternative for rural industries in developing countries.

\section{ACKNOWLEDGMENTS}

The authors express their gratitude to the following institutions that supported this research: Centro International de Agricultura Tropical CIAT , Consorcio CLAYUCA, and Universidad del Valle, all in Cali, Colombia.

\section{LITERATURE CITED}

Barona, S. M; Isaza, L. Estudios para el desarrollo de un proceso de extracción de almidón a partir de trozos secos de yuca con mínima utilización de agua. Universidad del Valle, Colombia. 2003. Engineering Thesis. http://www.clayuca.org/tesis.htm. 20 Jul. 2005.

Best, R.; Gómez, G. Procesamiento de las raíces de yuca para alimentación animal. In: Domínguez, C. Yuca: Investigación, producción y utilización, PNUD/CIAT, 1980. Documento de trabajo, n.50

Casal, J.; Martínez-Benet, J. M. A better way to calculate cyclone pressure drop. Chemical Engineering, v.90, n.2, p.99-100. 1983.

CIM-MICROSEP. - CIMPROGETTI. http://www.cimprogetti.it. 20 Jul. 2005.

Domínguez, C.; Ceballos, L. F.; Fuentes, C. Morfología de la planta de Yuca. In: Domínguez, C. Yuca: Investigación, producción y utilización, PNUD/CIAT, 1980. Documento de trabajo n. 50.

Dufour, D.; Alarcón F. Almidón agrio de yuca en Colombia. Tomo 1, Producción y recomendaciones. CIAT, publicación n.218, 1998. http://www.ciat.cgiar.org/down-loads/ onlinepublications.htm\#spanish. 20 Mar. 2007.

Duque, A. Proyecto para el control de los vertimientos generados en el beneficio de la yuca en el sector de Mondomo, Santander de Quilichao: Universidad del Valle, 1994, 36p. Engineering Thesis

FAO Noticias. Defensa de la causa de la yuca. http://www.fao.org/ Noticias/2000-/000405-s.htm. 20 Mar. 2007.

Presidencia de la República de Colombia. Plan Colombia, 2003. http://www.plancolom-bia.gov.co. 13 May. 2005.

Satin, M. Functional properties of starches. FAO, Agro-industries and post-harvest management service, 1999. http:// www.fao.org/ag/ags/agsi/starch41.htm. 20 Mar. 2007.

Shepherd, C. B.; Lapple, C. E. Flow pattern and pressure drop in cyclone dust collectors. Industrial and Engineering Chemistry, v.32, n.9, p.1246-1248, 1940.

Stairman, C. J. Pressure drop in cyclone separator. Engineering, v.16B, p.409-411, 1949.

Valdivieso García, M. A. Análisis de la cadena agroindustrial de productos amazónicos, proyecto desarrollo de agroempresas rurales, el consorcio para el desarrollo sostenible de Ucayali CODESU, Lima, Perú, 2000. http://www.ciat.cgiar.org/agroempresas/espanol/inicio.htm. 20 Mar. 2007. 